\title{
Assessing the Influence of Water Management and Rainfall Seasonality on Water Quality and Intestinal Parasitism in Rural Northeastern Brazil
}

\author{
Alexandre Pessoa Dias $(\mathbb{D}),{ }^{1,2}$ Deiviane Calegar $\left(\mathbb{D},{ }^{3}\right.$ Filipe Anibal Carvalho-Costa, ${ }^{3,4}$ \\ Maria de Fátima Leal Alencar, ${ }^{1}$ Caroline Ferraz Ignacio, ${ }^{1}$ \\ Milena Enderson Chagas da Silva, ${ }^{1}$ and Antonio Henrique Almeida de Moraes Neto ${ }^{1}$ \\ ${ }^{1}$ Fundação Oswaldo Cruz, Instituto Oswaldo Cruz, Laboratório de Inovações em Terapias, Ensino e Bioprodutos (LITEB), \\ Rio de Janeiro, Brazil \\ ${ }^{2}$ Fundação Oswaldo Cruz, Escola Politécnica de Saúde Joaquim Venâncio, \\ Laboratório de Educação Profissional em Vigilância em Saúde (LAVSA), Rio de Janeiro, Brazil \\ ${ }^{3}$ Fundação Oswaldo Cruz, Instituto Oswaldo Cruz, Laboratório de Epidemiologia e Sistemática Molecular (LESM), \\ Rio de Janeiro, Brazil \\ ${ }^{4}$ Escritório Técnico Regional Fiocruz Piauí, Brazil
}

Correspondence should be addressed to Alexandre Pessoa Dias; apessoadias@gmail.com

Received 22 December 2017; Accepted 19 June 2018; Published 18 July 2018

Academic Editor: Jean-Paul J. Gonzalez

\begin{abstract}
Copyright (C) 2018 Alexandre Pessoa Dias et al. This is an open access article distributed under the Creative Commons Attribution License, which permits unrestricted use, distribution, and reproduction in any medium, provided the original work is properly cited.

Introduction. The drought in the Brazilian semiarid region has affected the quality of water. This study assessed the relationships between enteric parasitoses, water management, and water quality, correlating them with pluviometric seasonality. Methods. Crosssectional surveys were carried out in four rural communities at the beginning of the dry season ( $\mathrm{n}=151)$, at the end of the dry season $(n=184)$, and in the rainy season $(n=199)$, in order to collect sociodemographic data, human fecal samples, and samples of the water used for human consumption for physicochemical and microbiological analyses. In 2015, water filters were provided to 30 households under study. Results. There was an increasing trend in detection rates of commensal protozoa and the Entamoeba histolytica/Entamoeba dispar complex at the beginning of the rainy season, with detection rates of 6\% in 2014 and $21.6 \%$ in 2016 . Giardia intestinalis and Ascaris lumbricoides presented distinct temporal distributions, which peaked in 2015: 20.1\% and 30\%, respectively. The proportion of inhabitants drinking inadequate water was $55 \%$ at the beginning of the dry season and $28.8 \%$ at the end of the dry season, reaching $70.9 \%$ at the beginning of the rainy season. The presence of filters reduced this proportion among those who received the hollow ceramic candle filter. Conclusions. Data suggest that the strategies to increase water supply in the Brazilian semiarid region can be ameliorated in order to improve the quality of drinking water.
\end{abstract}

\section{Introduction}

The World Health Organization (WHO) proposes that lowcost interventions for water treatment and safe storage in households bring significant improvements in water quality and, consequently, in the control of waterborne and diarrheal diseases $[1,2]$. The Brazilian semiarid region, located mainly in the Northeast region, covers $982,563.3 \mathrm{~km}^{2}$, nine states, and 1,133 municipalities with a population of 22.5 million inhabitants [3-5]. The Northeast region accounts for almost
$60 \%$ of the country's 16.3 million inhabitants currently living in extreme poverty; $56.4 \%$ live in rural areas [6] where only $33.4 \%$ of the households are connected to the water supply network and $5.1 \%$ to the sewage collection network [7].

In order to increase the water supply in the semiarid region, governmental initiatives have adopted rainwater harvesting in an attempt to utilize the strong pluviometric seasonality of the region, which is characterized by a rainy season concentrated in four months of the year [8]. In 2015, 
Brazil experienced the prolongation of one of the most severe droughts of the last 50 years, with its most critical period being between 2012 and 2014 [9]. In Brazil, the federal government's Water for All (Água para Todos) program has expanded the implementation of rainwater harvesting tanks, in accordance with guidelines of the Brazil without Extreme Poverty Plan [10, 11]. This program reached its target for the 2011-2014 period supplying 750,000 families in the Brazilian semiarid region. These families had limited access to drinkable water and depended on water sources that were unreliable or inappropriate for consumption [12]. According to data from the Ministry of Social and Agrarian Development, 1,257,670 cisterns were built in the semiarid region from 2003 to 2017 to harvest rainwater for human consumption [13]. In the case of the state of Ceará, there were 289,338 units for the same period. The cisterns are built with cement or polyethylene, have the capacity to store $16 \mathrm{~m}^{3}$ of rainwater, and are connected to the roofs of houses. During the rainy season, the rainwater harvested from the roof accumulates in the cistern. When it is full, the tank provides water for a family of up to five people for a period of up to eight months, which corresponds to a per capita consumption of about 14L/inhabitant/day [14].

Microbiological analyses of the cisterns' harvested rainwater point to the presence of contamination with coliforms in South Africa [15] and northeastern Brazil [16, 17]. On the other hand, research shows that the presence of cisterns represents a protection factor against diarrhea and intestinal parasites $[18,19]$. Therefore, water management must accompany the scaling up of the implementation of rainwater cisterns in order to achieve the control of waterborne diseases. It is possible that in addition to the greater supply of water through the use of cisterns improvements can be made to water quality. The present study aims to assess the correlation between human infection with intestinal parasites, water management, and water quality, correlating them with pluviometric seasonality, in four rural communities of a settlement in the Brazilian semiarid region.

\section{Population and Methods}

2.1. Description of the Study Area. The study was carried in the municipalities of Madalena and Quixeramobim of the State of Ceará, in four rural communities (São Joaquim Sede, São Joaquim Raiz, Quieto 1, and Quieto 2) with a total population of 455 inhabitants, belonging to the Settlement 25 de Maio (latitude: $5^{\circ} 1^{\prime} 40.52^{\prime \prime}$ S; longitude: $39^{\circ} 31^{\prime} 54.85^{\circ}$ ) with an area of 22,992 ha $[20,21]$. The region is characterized as being hot tropical semiarid (Köppen classification), with a dry and hot period from June to January with extremely low rainfall and a rainy period in February to May [22]. The average annual rainfall between 2012 and 2016 ranged from 299.2 to $461.9 \mathrm{~mm}$ per year. Considering that the historical average of the rainy season oscillates around $606 \mathrm{~mm}$, it was observed that, during the study period, there was an annual rainfall deficit between $24 \%$ and $51 \%$, illustrating the additional water stress to which the analyzed population was subjected.
2.2. Study Design. Cross-sectional surveys were carried out: (i) at the beginning of the dry season (July/August 2014 [ $n=40$ houses; 151 subjects]), (ii) at the end of the dry season (October 2015 [ $n=60$ houses; 184 subjects]), and (iii) in the rainy season (April/May 2016 [n=59 houses; 199 subjects]). Researchers collected sociodemographic data, fecal samples of the residents, and samples of the water used for human consumption. In 2015 water filters were provided to 30 (50\%) of households under study. Among the filters distributed, 15 had a traditional porous candle (hollow, without charcoal), classified as P-III (Brazilian Association of Technical Standards, Portuguese acronym ABNT) [23] with a particle retention range between 5 and $15 \mu \mathrm{m}$, and 15 had porous candles (with charcoal), classified as P-I with a retention range between 0.5 and $1 \mu \mathrm{m}$ (ABNT) [23]. Data were analyzed using the Epi-Info 7.0 Program, using chi-square or Fisher's exact test for comparison of proportions. The level of statistical significance was set at $\mathrm{p}<0.05$.

2.3. Parasitological Analyses of Feces. Fecal samples were collected from the residents in wide-mouth screw-cap containers with scoops, without preservatives. The samples were analyzed by the Lutz [24] technique (spontaneous sedimentation), with a reading of three slides per sample, stained by Lugol. The same experienced technician examined all samples. The parasitized individuals received treatment at home visits, under medical supervision of the local primary health unit of the respective municipalities, during the three campaigns.

\subsection{Physical-Chemical and Microbiological Analyses of Water.} From each household (except two in 2016) a $200 \mathrm{~mL}$ and 250 $\mathrm{mL}$ water sample was collected in a sterile flask (with sodium thiosulphate), for physicochemical and microbiological analysis, respectively. Samples were collected from the residential source, at a time-point directly before consumption by the inhabitants. The sources of water collected at the most recent point before consumption were varied, including rainwater, wells, ponds or bottled water, or water from the neighbors' house. The in situ measurements to determine the water sample $\mathrm{pH}$, electrical conductivity, dissolved oxygen, total dissolved solids, salinity, and temperature were performed using the Hanna ${ }^{\circledR}$ Instruments (São Paulo, Brazil) model HI9828 multiparameter probe. The analysis of water salinity followed that prescribed in National Council for the Environment's Resolution no. 357 (Conama 2005) [25], which classifies the waters into fresh water (salinity up to $0.05 \%$ ), brackish water (salinity from $0.05 \%$ to $3 \%$ ), and salt water (salinity above $3 \%$ ). To determine the physicochemical parameters turbidity and color and the microbiological parameters total coliforms and Escherichia coli, the water samples were sent with a maximum period of 24 hours to the Central Health Laboratory of Ceará (LACEN-CE), according to the collection procedures prescribed in the Manual for the Collection, Packaging, and Transport of Samples (Ceará 2013) and according to NBR ISO/IEC 17,025 (ABNT 2005). Water classification (adequate or inadequate), considering microbiological criteria, was based on the presence of Escherichia coli. Total coliform was not a criterion for classifying water as inadequate, since 
this includes environmental microorganisms not necessarily indicative of fecal contamination. Considering physicochemical criteria, water was classified as adequate or inadequate according to standards described in Administrative Rule no. 2914 of the Brazilian Ministry of Health [26]. The following techniques were performed in LACEN-CE: (i) turbidity: nephelometric method, 2130B, APHA 2012 [27]), (ii) apparent color (visual comparison method, 2120B, APHA 2012 [27]), and (iii) Escherichia coli and total coliforms: chromogenic/enzymatic substrate technique (9223B APHA 2012 [27]).

\section{Results}

3.1. Prevalence of Intestinal Parasite Infections in Different Climatic Seasons and Years. Table 1 shows the frequency of detection of different intestinal parasites in relation to sociodemographic characteristics. In 2014 households of 3-5 residents exhibited the highest prevalence of intestinal parasites. In 2015 all (7/7) species were found to be most prevalent in houses with more than 5 individuals and in 2016 this was true for 5 out of 7 species. As shown in Figures 1 and 2, there was an increase in detection rates of commensal protozoa and the Entamoeba histolytica/Entamoeba dispar complex in the year 2016, which corresponded to the beginning of the rainy season. In this fashion the detection rate of $E$. histolytica/E. dispar increased from $6.0 \%$ (9/151) in 2014 to $21.6 \%$ (43/199) in 2016. With respect to the commensal protozoa Entamoeba coli, there was an increase from 5.3\% (8/151) in 2014 to $26.6 \%$ (53/199) in 2016. Giardia intestinalis presented a distinct temporal distribution and together with Ascaris lumbricoides was detected more frequently in $2015(20.1 \%$ [37/184] and $30 \%$ [55/184], respectively), with a reduction in $2016(7.0 \%$ [14/199] and 3.0\% [6/199], respectively). The São Joaquim Raiz community tended to present higher prevalence rates for intestinal parasites in 2015 and 2016 (Figure 1). In relation to age groups, G. intestinalis infection tended to be more frequent in children up to nine years of age in the years 2015 and 2016, with prevalence rates reaching $21.6 \%$ and $16.3 \%$, respectively, in this age group. In 2014, prevalence of giardiasis fluctuated between $3 \%$ and $7.5 \%$ in distinct age groups. Considering E. histolytica/E. dispar, detection rates were higher in subjects aged 16 to 59 years, reaching $9.3 \%$ and $23.6 \%$ in the years 2015 and 2016, respectively. In 2014, prevalence with E. histolytica/E. dispar reached $16.7 \%$ among individuals aged $>60$ years. Ascariasis was present in all age groups, with detection rates from $21.5 \%$ to $27.3 \%$ in different age groups in 2014 and from $16.2 \%$ to $38 \%$ in 2015 (Figure 2).

\subsection{Water Quality and Its Association with Infection by Intesti-} nal Parasites. The proportion of inhabitants drinking inadequate water was higher at the beginning of the dry season (2014) $(55.0 \%$ [83/151]) and at the beginning of the rainy season (2016), reaching $70.9 \%$ (141/199). In 2015, at the end of the dry season, $28.8 \%$ (53/184) of the studied subjects were consuming inadequate water (not shown). As observed in Table 2, there was no significant difference in the presence of different intestinal parasites in relation to the drinking water quality classified as satisfactory or unsatisfactory. In the three studied years, parasites such as G. intestinalis and E. histolytica/E. dispar were detected with similar frequencies among subjects drinking satisfactory or unsatisfactory water. Interestingly, in 2014, A. lumbricoides and Entamoeba coli were more frequently detected in subjects drinking satisfactory water.

3.3. Impact of Filters on the Prevalence of Intestinal Parasites and on Water Quality. As shown in Table 3, both types of water filters distributed in $2015 \mathrm{did}$ not affect the prevalence of different intestinal parasites in 2016. Nevertheless, filters influenced the microbiological quality of water. In 2016, the proportion of individuals consuming unsatisfactory water was 57.1\% (48/84) among those who received the hollow ceramic candle filter, $63.2 \%$ (43/68) among those who received the ceramic candle filter with charcoal, $77.4 \%(24 / 31)$ among those who already had a filter, and $95.1 \%$ (78/82) among those who did not use any type of filter at home $(\mathrm{p}<0.001)$. There was no statistically significant difference between the proportions of households with unsatisfactory water between the two types of ceramic candles used in household filters.

\section{Discussion}

This study shows a higher presence of infection with intestinal protozoa when compared to soil-transmitted helminthes, in accordance with a current trend of decrease in the prevalence of the latter [28]. Although some protozoa are not pathogenic, they can be considered indicators of water quality, since they are waterborne organisms transmitted by the fecal-oral route.

Mass drug administration in Brazil prioritizes the use of anthelmintic drugs (single $400 \mathrm{mg}$ oral Albendazole dose), in the context of the integrated plan of action for the elimination of neglected diseases [29]. Consonant with the recommendations of WHO, these strategies do not include intestinal protozoa, which can lead to an increase in the prevalence of these organisms [30]. In the studied region, treatment for soil-transmitted helminthes is performed by the primary healthcare system.

In the case of the E. histolytica/E. dispar complex it is necessary to carry out specific diagnostic tests to differentiate them. Estimates indicate that E. dispar is about ten times more frequent than E. histolytica and with a wide geographic distribution [31]. A study carried out in Ceará demonstrated that E. dispar is more frequent than E. histolytica in a scenario of drought [32]. Infection with G. intestinalis is also common in the studied localities. Studies have demonstrated that chronic and apparently asymptomatic infection with $G$. intestinalis negatively affects the nutritional status of children in developing countries [33]. This study demonstrated that prevalence of waterborne commensal protozoa (Endolimax nana, Iodamoeba butschlii, and Entamoeba coli) and E. histolytica/E. dispar tends to increase in the rainy season, when water is more abundant and the harvesting of rainwater begins. This coincides with a higher proportion of dwellers ingesting inadequate water. The prolongation of the drought in the studied period has resulted in the search for different sources of water for consumption, including the water 


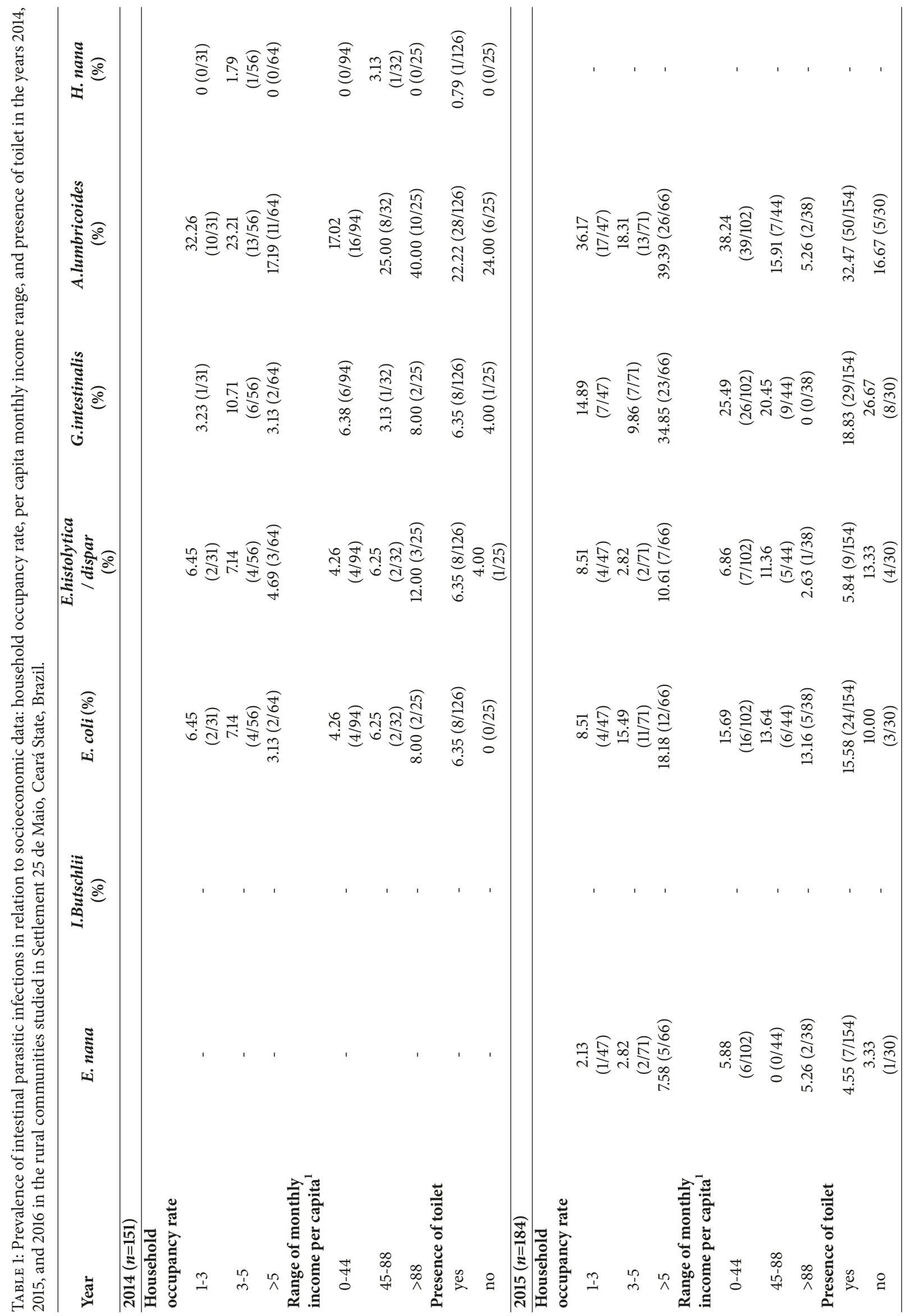




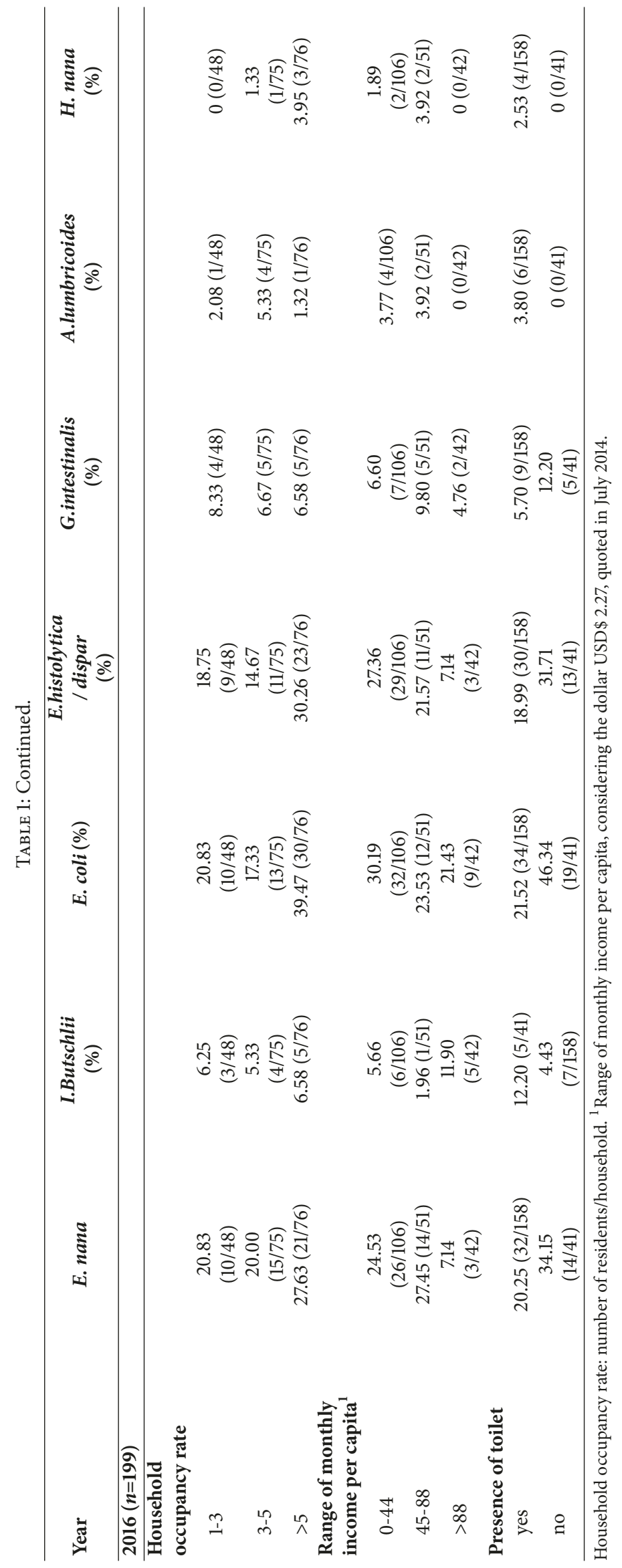



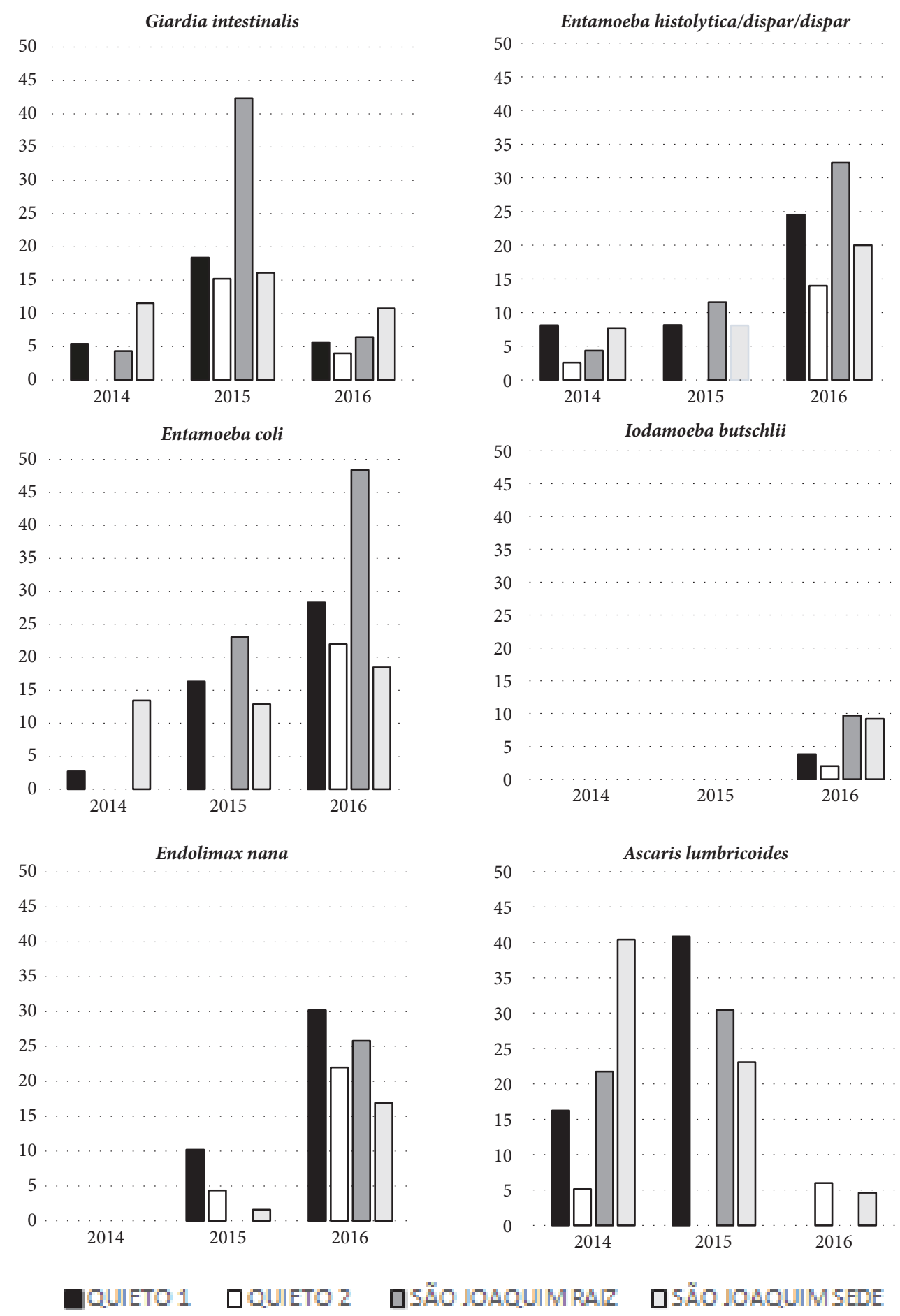

Figure 1: Prevalence of intestinal parasitoses in the communities Quieto 1, Quieto 2, São Joaquim, Sede, and São Joaquim, Raiz, of Assentamento 25 de Maio, Ceará, in the years 2014, 2015, and 2016.

transported by truck from dams and rivers distant from the settlement. The higher occurrence of unsatisfactory drinking water from households in the rainy season suggests that there is a greater contamination of water supply and, therefore, a correlation between the beginning of the rainy season and the increase in the prevalence of intestinal parasites. Early rainwater promotes the cleaning of roofs and water margins, resulting in the transport of pathogens into natural reservoirs and cisterns.

Data suggests an ecological association, at the community level, between the increase in prevalence of some species of enteric protozoa and the decrease of water quality at the 

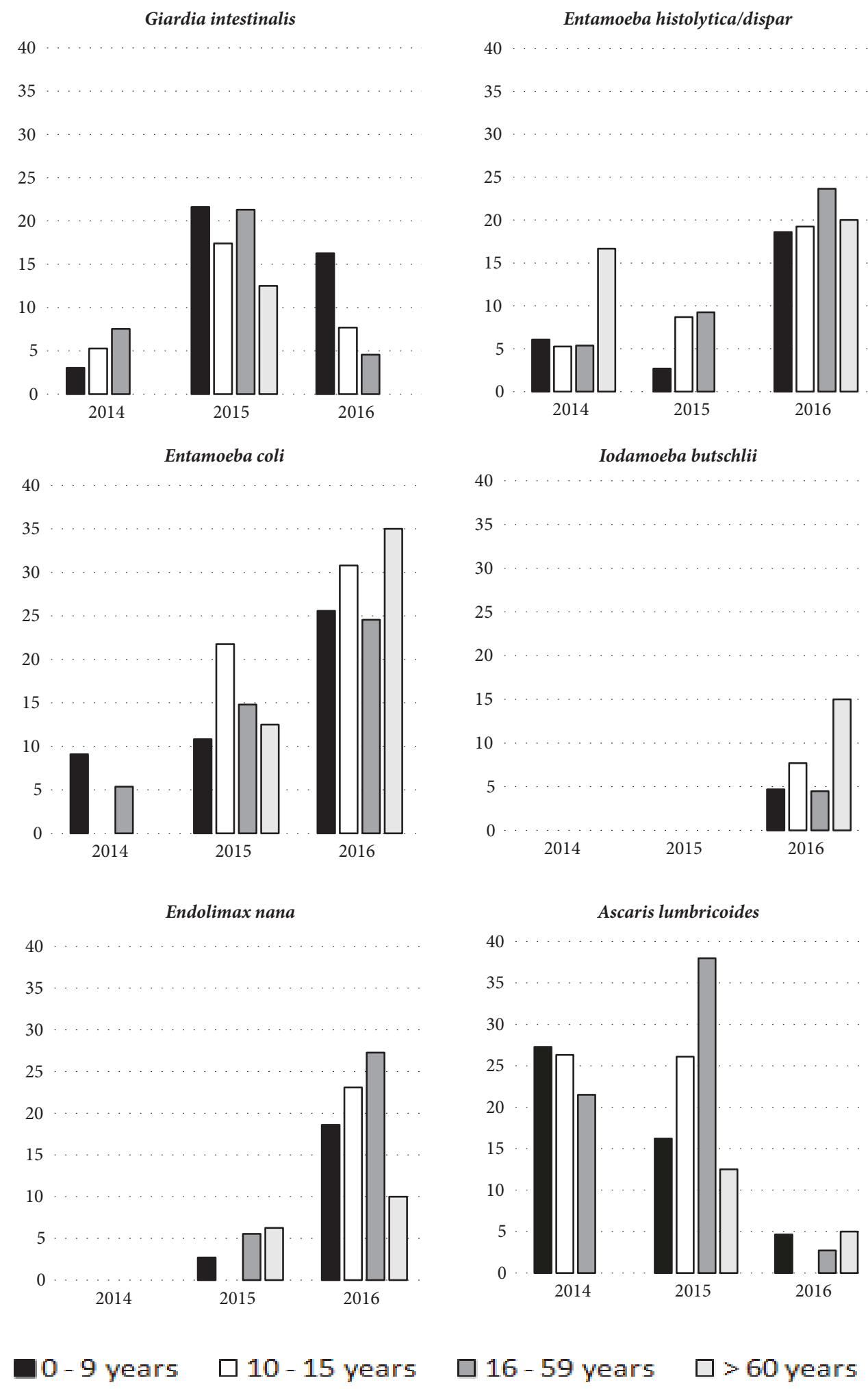

Figure 2: Prevalence of intestinal parasitoses by age group in Assentamento 25 de Maio, Ceará, in the years 2014, 2015 , and 2016. 


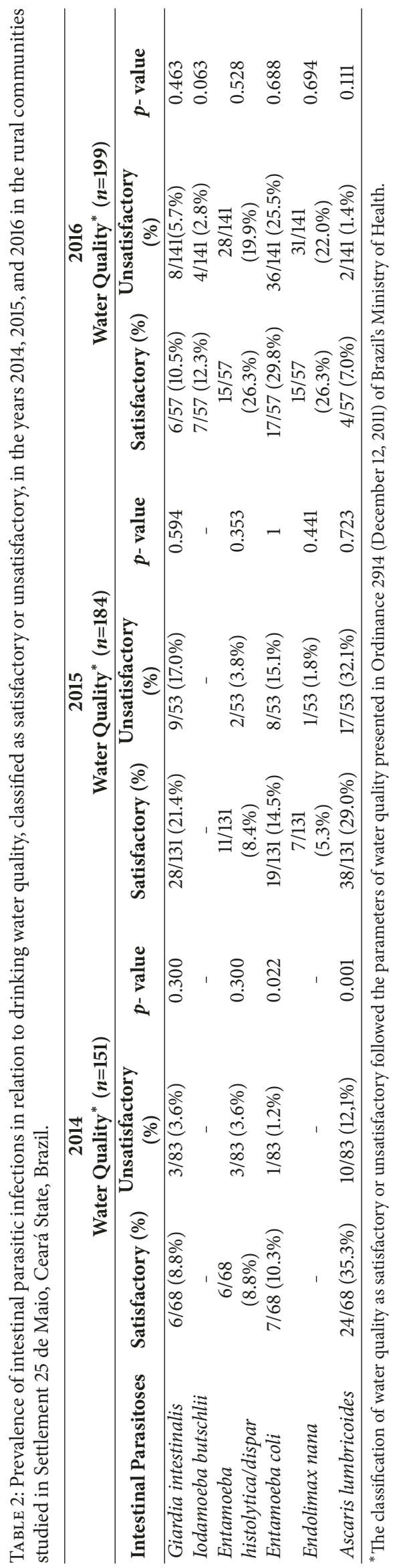


TABLE 3: Prevalence of intestinal parasitic infection in relation to the use of household-based water filters in 2016 in rural communities studied in Settlement 25 de Maio, Ceará State, Brazil.

\begin{tabular}{|c|c|c|c|c|c|}
\hline \multicolumn{6}{|c|}{ Household-based water filter } \\
\hline Intestinal Parasites & Type $0(\%)$ & Type $1(\%)$ & Type 2 (\%) & Type 3 (\%) & $p$-value \\
\hline Giardia intestinalis & $5 / 66(7.6)$ & $4 / 48(8.3)$ & $1 / 24(4.2)$ & $4 / 61(6.6)$ & 0.924 \\
\hline Entamoeba histolytica & $16 / 66(24.2)$ & $6 / 48(12.5)$ & $10 / 24(41.7)$ & $11 / 61(18.0)$ & 0.032 \\
\hline Entamoeba coli & $18 / 66(27.3)$ & $14 / 48(29.2)$ & $11 / 24(45.8)$ & $10 / 61(16.4)$ & 0.046 \\
\hline Endolimax nana & $15 / 66(22.7)$ & $10 / 48(20.8)$ & $7 / 24(29.2)$ & $14 / 61(23.0)$ & 0.886 \\
\hline Iodamoeba butschlii & $15 / 66(22.7)$ & $2 / 48(4.2)$ & $2 / 24(8.3)$ & $3 / 61(4.9)$ & 0.818 \\
\hline Ascaris lumbricoides & $1 / 66(1.5)$ & $3 / 48(6.3)$ & $0 / 24(0.0)$ & $2 / 61(3.3)$ & 0.393 \\
\hline
\end{tabular}

Types: 0: ceramic candle filter (hallow); 1: ceramic candle filter (with coal); 2: existing ceramic candle filter (unknown interior); 3: not using a household-based water filter.

beginning of the rainy season. Nevertheless, at the individual level such an association could not be demonstrated, since rates were similar among inhabitants drinking microbiologically adequate or inadequate water. This lack of association between the microbiological quality of water and infection by intestinal parasites (including a higher positivity for $A$. lumbricoides and Entamoeba coli in people who drink water of satisfactory quality) was an interesting finding of this work. This suggests a dissociation, at the domiciliary level, between the microbiological quality of water and the transmission of intestinal parasites. This transmission, therefore, should have more complex dynamics and involve other aspects and determinants, independents of the bacterial contamination of the water and involving the domestic, peridomestic, and working (agricultural) environment. Lack of association at the individual level indicates the possibility of water consumption in several households beyond that actually inhabited by the subject. In addition, water quality analyses do not consider the presence of infectious forms of intestinal parasites, so that, theoretically, microbiologically satisfactory water could be contaminated with intestinal parasitic cysts and eggs. This possibility is supported by the fact that these structures are less sensitive to water chlorination.

Although the protective effect of the filters on intestinal parasites was not observed, a significantly lower proportion of inadequate water consumption was observed among the families that received the filters. This shows that the filters have a positive impact on the quality of the water to be consumed and can influence the transmission of bacterial waterborne diseases. Previous studies indicate the efficiency of the filter in the removal of bacteria such as Escherichia coli and total coliforms from drinking water in rural Bolivia and South Africa $[34,35]$.

\section{Conclusions}

The data suggest that the strategies to increase water supply in the Brazilian semiarid region can include improvements in the quality of rainwater harvested for human consumption. In this sense, the distribution of household-based filters can be considered an effective solution when used in conjunction with rainwater harvesting systems and chlorination, which should be made available to low-income rural inhabitants. Periodic assessments of the water quality of cisterns should be conducted, with emphasis on microbiological aspects. Also, water supply expansion programs in Brazil should incorporate household water treatment with health education to serve as a sanitation barrier for the control of intestinal parasitic infections.

\section{Conflicts of Interest}

The authors declare that they have no conflicts of interest.

\section{References}

[1] M. D. Sobsey, Managing water in the home: accelerated health gains from improved water supply, World Health Organization, Geneva, 2002.

[2] World Health Organization. A toolkit for monitoring and evaluating household water treatment and safe storage programmes. Geneva: WHO/Unicef; 2012. http://www.who.int/ household_water/WHO_UNICEF_HWTS_MonitoringToolkit_ 2012.pdf.

[3] Brasil. Ministério da Integração Nacional. Grupo de trabalho interministerial para redelimitação do semiárido nordestino e do polígono das secas. Relatório final. 2005. http://www.mi .gov.br/c/document_library/get_file?uuid=090e3f78-bde3-4alba46c-da4bla0d78fa\&amp;groupId=10157.

[4] Brasil. Presidência da República. Casa Civil. Portaria no. 89, de 16 de março de 2005. Atualiza a relação dos municípios pertencentes à região Semiárida do Fundo Constitucional de Financiamento do Nordeste - FNE.

[5] Instituto Brasileiro de Geografia e Estatística (IBGE). Censo Demográfico 2010. Características da população e dos domicílios: resultados do universo. [Internet]. Rio de Janeiro: IBGE; 2010. http://www.ibge.gov.br/home/estatistica/populacao/censo2010/default.shtm.

[6] Brasil. Ministério do Desenvolvimento Social e Combate à Fome. Nota MDS: O perfil da extrema pobreza no Brasil com base nos dados preliminares do universo do Censo de 2010. Brasília: Ministério do Desenvolvimento Social e Combate à Fome; 2011. 7p.

[7] Instituto Brasileiro de Geografia e Estatística (IBGE). Pesquisa nacional por amostra de domicílios (PNAD). [Internet]. Rio de Janeiro: IBGE; 2014. http://www.ibge.gov.br/home/estatistica/ populacao/trabalhoerendimento/pnad2014/.

[8] R. Malvezzi, Semi-Árido, Confea, Uma visão Holística, Brasília, 2007. 
[9] T. A. Alpino, A. R. Sena, and C. M. Freitas, "Desastres relacionados à seca e saúde coletiva - uma revisão da literatura científica," Ciência \& Saúde Coletiva, vol. 21, no. 3, pp. 809-820, 2016.

[10] Brasil. Presidência da República. Casa Civil. Decreto nº. 7535, de 26 de julho de 2011. Institui o Programa Nacional de Universalização do Acesso e Uso de Água - “Água para Todos”. http:// www.planalto.gov.br/ccivil_03/_Ato2011-2014/2011/Decreto/ D7535.htm.

[11] Brasil. Presidência da República. Casa Civil. Decreto n7.492, de 2 de junho de 2011. Institui o Plano Brasil Sem Miséria. 2011.

[12] Brasil. Secretaria de Vigilância em Saúde. Ocorrência de cianobactérias nos municípios monitorados em 2012. Boletim Epidemiológico. Secretaria de Vigilância em Saúde. 2014;(45)1. http://portalsaude.saude.gov.br/images/pdf/2014/junho/11/BE2014-45-1-Cianobact-rias.pdf.

[13] Brasil. Ministério do Desenvolvimento Social e Agrário. Área de Imprensa. Dados. Brasil: Ministério do Desenvolvimento Social e Agrário. 2016. http://mds.gov.br/area-de-imprensa/dados.

[14] L. T. L. Brito, A. S. Silva, E. R. Porto, M. C. C. Amorim, and W. M. Leite, Cisternas domiciliares: água para consumo humano. Embrapa Semiárido, Portal Embrapa, Brasília, 2007.

[15] P. H. Dobrowsky, A. van Deventer, M. De Kwaadsteniet et al., "Prevalence of virulence genes associated with pathogenic Escherichia coli strains isolated from domestically harvested rainwater during low- and high-rainfall periods," Applied and Environmental Microbiology, vol. 80, no. 5, pp. 1633-1638, 2014.

[16] R. P. Xavier, L. P. Siqueira, F. A. C. Vital, F. J. S. Rocha, J. I. Irmão, and G. M. T. Calazans, "Microbiological quality of drinking rainwater in the inland region of pajeú, pernambuco, Northeast Brazil," Revista do Instituto de Medicina Tropical de São Paulo, vol. 53, no. 3, pp. 121-124, 2011.

[17] F. Alves, T. Köchling, J. Luz, S. M. Santos, and S. Gavazza, "Water quality and microbial diversity in cisterns from semiarid areas in Brazil," Journal of Water and Health, vol. 12, no. 3, pp. 513-525, 2014.

[18] J. E. Fonseca, M. Carneiro, J. L. Pena et al., "Reducing Occurrence of Giardia duodenalis in Children Living in Semiarid Regions: Impact of a Large Scale Rainwater Harvesting Initiative," PLOS Neglected Tropical Diseases, vol. 8, no. 6, p. e2943, 2014.

[19] P. B. Marcynuk, J. A. Flint, J. M. Sargeant et al., "Comparison of the burden of diarrhoeal illness among individuals with and without household cisterns in northeast Brazil," BMC Infectious Diseases, vol. 13, no. 1, 2013.

[20] C. F. Coelho, L. S. Pinheiro, J. C. Ara.jo, and M. C. Wiegand, "Tecnologia fossa verde como estratégia de saneamento rural no semiárido: o caso do Assentamento 25 de Maio, Ceará," in 50o Congresso da Sociedade Brasileira de Economia, p. 14p, Administração e Sociologia Rural, Vitória, ES, 2012.

[21] Instituto Nacional de Colonização e Reforma Agrária (Incra). Plano de desenvolvimento do PA 25 de Maio. Cooperativa Central das Áreas de Reforma Agrária do Ceará. Cooperativa de Prestação de Serviço e Assistência Técnica. 1997.

[22] Instituto de Pesquisa e Estratégia Econômica do Ceará (Ipece). 2014. Perfil básico municipal de Madalena. Secretaria do Planejamento e Gestão. Ceará: Governo de Estado do Ceará. 18p. Fundação Cearense de Meteorologia e Recursos Hídricos (Funceme). http://www.funceme.br.

[23] Associação Brasileira de Normas Técnicas. NBR 16098: Aparelho para melhoria da qualidade da água para consumo humano - Requisitos e métodos de ensaio. Rio de Janeiro: ABNT; 2012.
[24] A. Lutz, Schistosomum mansoni and Shistosomatosis observed in Brazil, vol. 11, Mem Inst Oswaldo Cruz, 1919.

[25] Conselho Nacional de Meio Ambiente (Conama). Resolução n.o 357, de 17 de março de 2005. Dispõe sobre a classificação dos corpos de água e diretrizes ambientais para o seu enquadramento, bem como estabelece as condições e padrões de lançamento de efluentes, e dá outrasprovidências. Disponívelem http://www.mma.gov.br/port/conama/res/res05/res35705 .pdf.

[26] Brasil. Ministério da Saúde. Portaria nº. 2914, de 12 de dezembro de 2011. Dispõe sobre os procedimentos de controle e vigilância da qualidade da água para o consumo humano e seu padrão de potabilidade.

[27] APHA, AWWA, WPCF. Standard methods for the examination of water and waste-water. American Public Health Association. 22nd edition. Washington. DC: APHA, 2012.

[28] B. C. Nunes, M. G. Pavan, L. H. Jaeger et al., "Spatial and Molecular Epidemiology of Giardia intestinalis Deep in the Amazon, Brazil," PLoS ONE, vol. 11, no. 7, Article ID e0158805, 2016.

[29] Brasil. Ministério da Saúde. Plano Integrado de Ações Estratégicas de Eliminação da Hanseníase, Filariose, Esquistossomose e Oncocercose como Problema de Saúde Pública, Tracoma como Causa de Cegueira e Controle das Geohelmintíases: Plano de Ação 2011-2015. Brasília: Ministério da Saúde. 2012.

[30] J. A. Turkeltaub, T. R. McCarty III, and P. J. Hotez, "The intestinal protozoa: Emerging impact on global health and development," Current Opinion in Gastroenterology, vol. 31, no. 1, pp. 38-44, 2015.

[31] L. Rey, Parasitologia, Rio de Janeiro, Guanabara Koogan, 4th edition, 2011.

[32] D. A. Calegar, B. C. Nunes, K. J. L. Monteiro et al., "Frequency and molecular characterisation of Entamoeba histolytica, Entamoeba dispar, Entamoeba moshkovskii, and Entamoeba hartmanni in the context of water scarcity in northeastern Brazil," Memórias do Instituto Oswaldo Cruz, vol. 111, no. 2, pp. 114-119, 2016.

[33] R. Ignatius, J. B. Gahutu, C. Klotz et al., "High prevalence of giardia duodenalis assemblage $\mathrm{b}$ infection and association with underweight in rwandan children," PLOS Neglected Tropical Diseases, vol. 6, no. 6, Article ID e1677, 2012.

[34] T. F. Clasen, J. Brown, S. Collin, O. Suntura, and S. Cairncross, "Reducing diarrhea through the use of householdbased ceramic water filters: A randomized, controlled trial in rural Bolivia," The American Journal of Tropical Medicine and Hygiene, vol. 70, no. 6, pp. 651-657, 2004.

[35] J. K. Mwabi, B. B. Mamba, and M. N. B. Momba, "Removal of waterborne bacteria from surface water and groundwater by cost-effective household water treatment systems (HWTS): A sustainable solution for improving water quality in rural communities of Africa," Water SA, vol. 39, no. 4, pp. 445-456, 2013. 


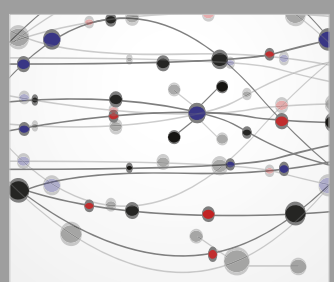

The Scientific World Journal
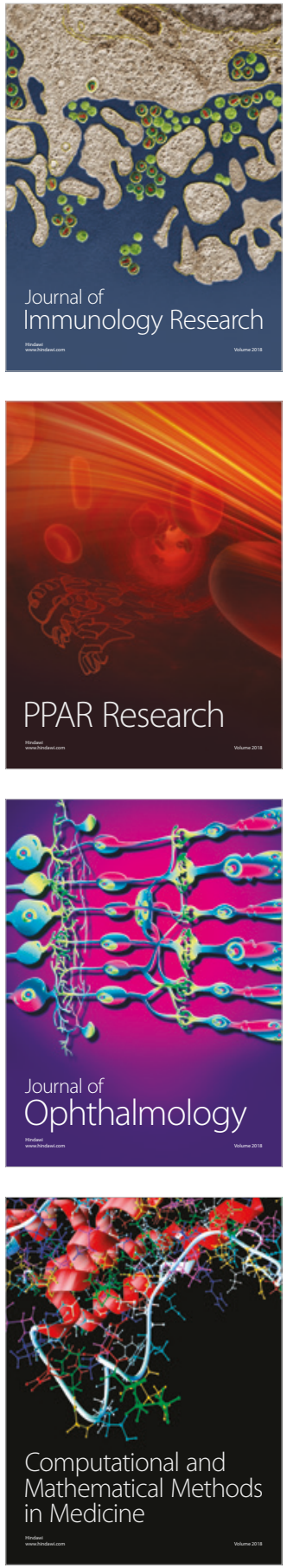

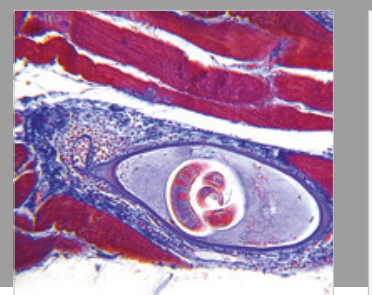

Gastroenterology Research and Practice

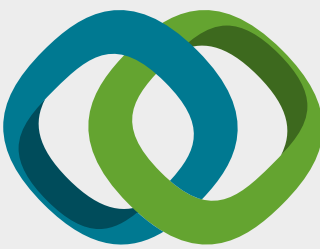

\section{Hindawi}

Submit your manuscripts at

www.hindawi.com
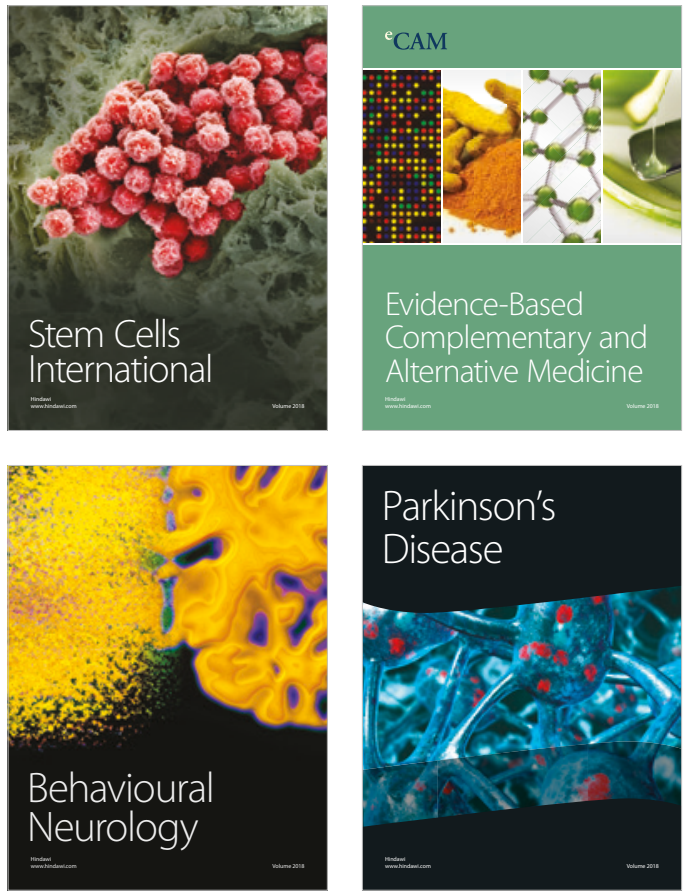

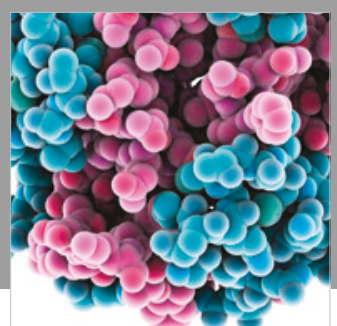

ournal of

Diabetes Research

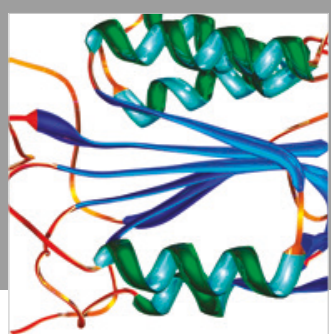

Disease Markers
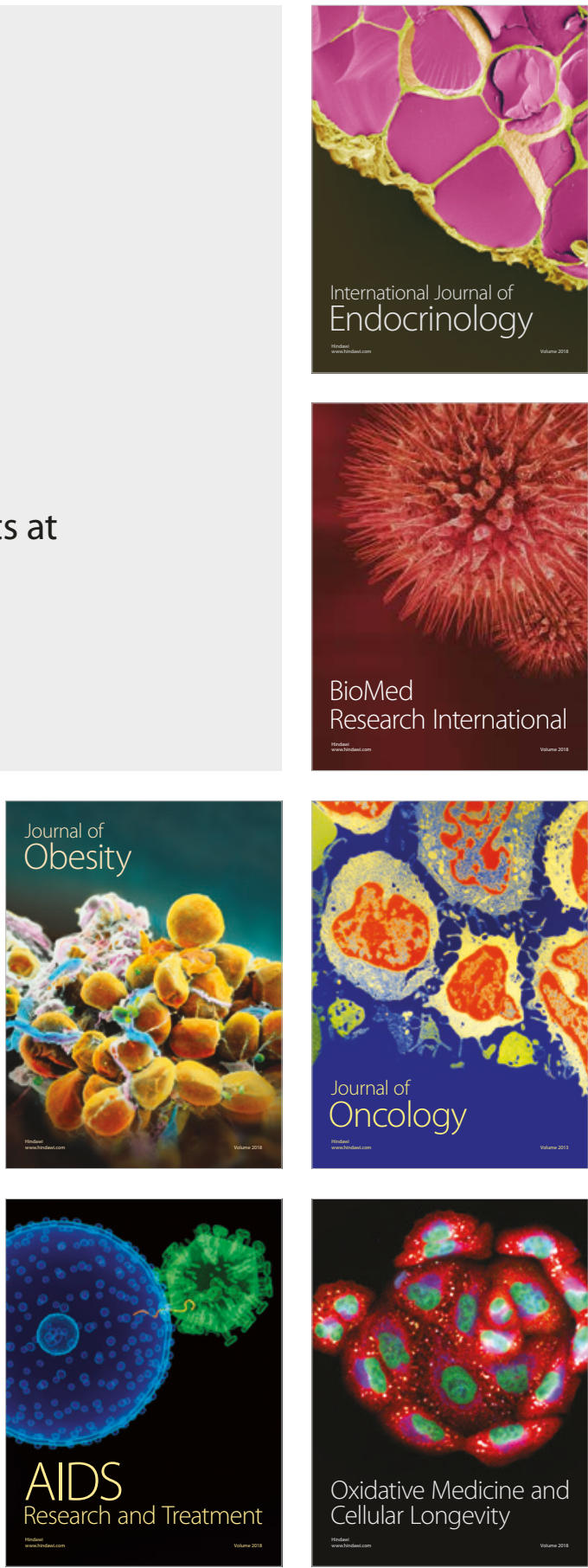